Indonesian Journal of Biotechnology, June, 2012

Vol. 17, No. 1, pp.51-60

\title{
Gynura procumbens Prevents Chemoresistance through Inhibition MDR1 Expression on MCF-7 Breast Cancer Cell Line and Sensitizes the Cells to Doxorubicin
}

\author{
Nunuk Aries Nurulita ${ }^{1,2 *}$,Edy Meiyanto ${ }^{3}$, Sugiyanto ${ }^{3}$, Eishou Matsuda ${ }^{4}$, \\ and Masashi Kawaichi ${ }^{4}$
}

\footnotetext{
${ }^{1}$ Faculty of Pharmacy Universitas Muhammadiyah Purwokerto, Purwokerto, Indonesia

${ }^{2}$ Graduate Program of Pharmaceutical Science, Faculty of Pharmacy, Universitas Gadjah Mada, Yogyakarta, Indonesia

${ }^{3}$ Cancer Chemoprevention Research Centre, Faculty of Pharmacy, Universitas Gadjah Mada, Yogyakarta, Indonesia

${ }^{4}$ Laboratorium of Gene Function of Animal, Nara Institute of Science and Technology, Nara, Japan
}

\begin{abstract}
The long-term exposure of doxorubicin (Dox) causes enhancement in MDR1 expression that leads to breast cancer cell resistance. This protein become a serious problem in cancer treatment and also well-known as negative prognostic factor in breast cancer malignancies. The new approach using natural chemopreventive substance was developed to inhibit this resistance progress. This study was aimed to investigate whether ethyl acetate fraction of Gynura procumnens (FEG) can prevent chemoresistance through suppressing the MDR1 protein expression. MCF-7 cell was used as chemoresistance cell model. The MCF-7 cells were maintained with 100 nM Dox-contained medium for five weeks. The chemoprevention effect of FEG was investigated by treated MCF-7/Dox with sub-toxic concentration of FEG. The cytotoxic properties of MCF-7 cells were determined using MTT (3-(4,5-dimethylthiazol-2-yl)-2,5-diphenyl-2H-tetrazolium bromide) assay. Immunofluorescence and western blotting analysis was performed to detect the MDR1 expression. MCF-7/Dox cells need higher concentration for inhibiting cell growth, were compared with MCF-7, shown by $\mathrm{IC}_{50}$ value. The MDR1 protein level elevated after Dox exposure in time dependent manner. The FEG treatment decreased MDR-1 protein level with dose dependent manner. FEG in combination with DOX potentiates the DOX effect on breast cancer cell growth inhibition. The FEG prevents the chemoresistance development in breast cancer cell line, MCF-7 induced by Dox through inhibiting MDR1 expression. The additional of FEG enhances Dox effect on cell death induction. Thus, FEG could be developed as co-chemotherapy agent for reverse multidrug resistance.
\end{abstract}

Keywords : Gynura procumbens, Chemoresistance, MDR1, MCF-7, MCF-7/Dox

\section{Introduction}

Drug resistance becomes a major obstacle to the successful of cancer chemotherapy. There are several mechanisms mediate the drug resistance mechanism including

\section{*Corresponding author:}

Nunuk Aries Nurulita,

Faculty of Pharmacy Universitas Muhammadiyah Purwakerto, Jl. Raya Dukuhwaluh, Kembaran,

Purwokerto, Jawa Tengah Indonesia

Telp. : +62-281-636751,

E-mail: nunuknurulita@yahoo.com drug inactivation, drug efflux, drug target mutation, and the failure of apoptosis inisitian (Davis et al., 2003; Notarbartolo et al., 2005). Over expression of drug transporter such as P-gp plays a major role in causing multi drug resistance. $\mathrm{P}-\mathrm{gp}$ is an adenosine triphosphatase (ATPase), a member of ATPbinding cassette $(\mathrm{ABC})$ transporter encoded by $M D R 1$ gene. In normal cells, P-gp licalized at ephitel cell and has a functioan to eliminate xenobiotic and metabolit endogen. However, in some human cancers P-gp overexpression has high corelation with the decreasing 
survival and become poor prognosis on cancer development (Leonessa and Clarke, 2003). There is positive corelation between overall MDR1 expression and grade of breast cancer tumor (Surowiak et al., 2005). This protein become a serious problem in cancer treatment and also well-known as negative prognostic factor in breast cancer malignancies.

P-gp substrates include substances in variable structure, chemical properties and drug mechanism. Several cancer chemotherapy drugs such as anthracyclines, taxanes, and epipodhophylotoxins already well-known as the substrate of this protein. Long time exposure of these agents on cancer cells triggers the transcriptional activity of MDR1 lead the increasing of P-gp (Germann, 1996; Nielsen et al., 1996). The elevation of P-gp protein leads to chemotherapy failure due to cell resistance at several type of cancer. Doxorubicin which belongs to anthracyclin group could induce breast cancer multi drug resistance after long time exposure. DOX treatment increase P-gp expression level through Ras/Raf1 activation (Davis et al., 2003). P-gp-mediated drug efflux decreases intracellular Dox uptake and decrease its efficacy.

The development of P-gp inhibitors led to the third generation. Unfortunately, most of P-gp inhibitors that have been developed giving disappointing results. New approach using natural substances with moderate or low cytotoxic properties become a promising hope for reversing multi drug resistance due to $M D R 1$ over expression. Natural flavonoids have antitumor properties and others pharmacological activities related with its antitumor such as anti-inflammatory and antioxidant. Flavonoid, especially flavones and flavonol show modulation effect on cancer cell growth through cell cycle arrest and apoptosis induction (Limtrakul et al., 2007). Quercetin and kaempferol down regulate multidrug resistance gene on human erythroleukemic K562/ A cells. It causes decreasing of cells sensitivity to adriamycin
(Yanqiu et al., 2011). Quercetin sensitizes cell resistance to daunorubicin through suppression on MDR1 expression and P-gp activity at human pancreatic carcinoma (Borska et al., 2010).

Gynura procumbens is commonly used as herbal medicines in South-East Asia, especially Indonesia, Malaysia, and Thailand. The extract and fraction of this plant have high anti-inflammatory and antioxidant properties (Iskander et al., 2002; Rosidah et al., 2008). The ethyl acetate fraction of G. procumbens (FEG) may contain quercetin and kaempferol. FEG sensitizes MCF-7 breast cancer cells to Doxorubicin treatment led to cell death. FEG modulates the microtubule integrity followed by cell cycle arrest and cell growth inhibition (Nurulita et al., 2012). In this study, we subject FEG to doxorubicin-resistance cell. We use MCF-7 cells treated by $100 \mathrm{nM}$ doxorubicin for five week as a model of cell resistance. We investigate the modulation on their sensitivity to doxorubicin, P-gp level, and cell growth.

\section{Materials and Methods \\ Plant material}

The leaves of G. Procumbens were obtained from Balai Penelitian dan Pengembangan Tanaman Obat dan Obat Tradisional (BP2TO2T) Indonesia. Dried powdered leaves were first extracted with ethanol $96 \%$, and concentrated by evaporation under reduced pressure and the temperature was kept below $40^{\circ} \mathrm{C}$. The extract was diluted in hot water and then fractionated with n-hexane. The aqueous fraction then was fractionated again with ethyl acetate. The ethyl acetate fraction was concentrated by evaporation under reduced pressure and the temperature was kept below $40^{\circ} \mathrm{C}$. The extract was stored at $4^{\circ} \mathrm{C}$ until used.

\section{Cells and chemicals}

MCF-7 cells were obtained from Laboratorium of Gene Function in Animal, Nara Institute of Science and Technology (NAIST), Japan. MCF-7/DOX cells were 
developed from MCF-7 cell that induced with $100 \mathrm{nM}$ DOX for five weeks. The resistance development was checked by P-gp levels. The MCF-7 cells were routinely growed in DMEM (Nacalay Tesque) supplemented with 10\% FBS (PAA Laboratories), 1\% v/v Penicillinstreptomycin (Sigma), and $1 \mathrm{mM}$ L-glutamine (Nacalay Tesque) at $37^{\circ} \mathrm{C}$ in $5 \% \mathrm{CO} 2 . \mathrm{MCF}-7 /$ DOX cells were maintained in $25 \mathrm{nM}$ DOXcontained medium. Doxorubicin (DOX) and 5-Fluorouracil (5-FU) (Ebewe) was purchased from PT. Ferron Par Pharmaceutical Cikarang, Indonesia, Dimethyl sulfoxide (DMSO) (Sigma, Aldrich, Germany), penicillin and streptomycin (Gibco), Tripsin (Sigma), 3-(4,5dimethyltiazol-2-il)-2,5-diphenyltetrazolium bromide (MTT) (Sigma), triton X-100, 4',6-diamidino-2-phenylindole (DAPI) (Invitrogen) are at analytical degree.

\section{Antibodies}

Primary antibodies that used in western blotting and immunostaining were anti P-Glycoprotein (JSB-1) (GeneTex, Inc.), anti a-Tubulin (Santa Cruz), and secondary antibodies were diluted in PBS containing $5 \%$ skim milk, 0,05\% Tween (blocking buffer). For P-gp detection, the anti-P-gp and its secondary antibody were diluted in Can Get Signal (CGS) solution (Cosmo Bio).

\section{Cells growth assay}

Cells $\left(10^{4}\right.$ cells/well $)$ were seeded in 96-well plate (100 $\mu \mathrm{l} /$ well). After $24 \mathrm{~h}$ of incubation, the medium was replaced with DOX, FEG, and its combination-containing medium. The medium was discarded and replaced with MTT-containing medium $(0.5$ $\mathrm{mg} / \mathrm{ml}$ ) after $24 \mathrm{~h}$ incubation and incubated again for further $4 \mathrm{~h}$ at $37^{\circ} \mathrm{C}, 5 \% \mathrm{CO}_{2}$. The reaction was stopped using $10 \%$ SDS in $0.1 \mathrm{~N}$ $\mathrm{HCl}$ solution and was incubated for overnight in light protected chamber, to dissolve formasan salt. The absorbance of each well was measured by ELISA reader at $595 \mathrm{~nm}$. The ratio between treated and control cells absorbance referred to percentage $(\%)$ of cells viability.

\section{Gel electrophoresis and immunoblotting}

Cells were recovered, washed in PBS, and lysed for $30 \mathrm{~min}$ on ice using lysis buffer (20 mM Tris- $\mathrm{HCl}, \mathrm{pH} 8,0.5 \mathrm{mM}$ EDTA, 1\% $\mathrm{NP} 40,25 \mathrm{mM} \mathrm{NaCl}$, and complete inhibitors of protease. Cells extract were centrifuged at $15.000 \mathrm{rpm}$ for $20 \mathrm{~min}$ at $4^{\circ} \mathrm{C}$ to separate insoluble material. The protein concentration was determined using Bradford assay. Equal amount of each sample were mixed with SDS loading buffer, boiled for $3 \mathrm{~min}$ and subjected to SDS-PAGE at $120 \mathrm{~V}$ followed by electro blotting to Polyvinylidene fluoride (PVDF) membranes for $2 \mathrm{~h}$ at $100 \mathrm{~V}$. Membranes were blocked using 5\% skim milk in PBS at room temperature for 1 hand subsequently probed with the primary antibody of interest. Blots were exposed by Chemilumi-oneSuper (Nacalay Tesque).

\section{Results}

Long treatment of sub toxic concentration of DOX induced resistance cells development.

Breast cancer cells become less sensitive to chemotherapy agen during the cells resistance development. After five weeks induced by DOX, MCF-7 cells decreased its sensitivity to DOX treatment, as shown by $\mathrm{IC}_{50}$ value (Table 1$)$.

Table $1 . \mathrm{IC}_{50}$ value of DOX and FEG on MCF-7 and MCF-7/DOX cells

\begin{tabular}{llrr}
\hline Sample & Cell Line & \multicolumn{2}{c}{ IC $_{50}$ value $^{*}$} \\
\hline DOX & MCF-7 & $410 \pm 44$ & $\mathrm{nM}$ \\
& MCF-7/Dox & $921 \pm 40$ & $\mathrm{nM}$ \\
FEG & MCF-7 & $259 \pm 29$ & $\mu \mathrm{g} / \mathrm{ml}$ \\
& MCF-7/Dox & $161 \pm 40$ & $\mu \mathrm{g} / \mathrm{ml}$ \\
\hline
\end{tabular}

*average from two independent experiments

DOX resulted cell growth inhibition more than 2-fold higher on MCF-7/DOX sub line than that of MCF-7 cell line (Figure 1A). FEG treatment showed the opposite results. FEG caused cell growth inhibition stronger on MCF-7/DOX sub line compared with MCF-7 cell (Figure 1B). 
A

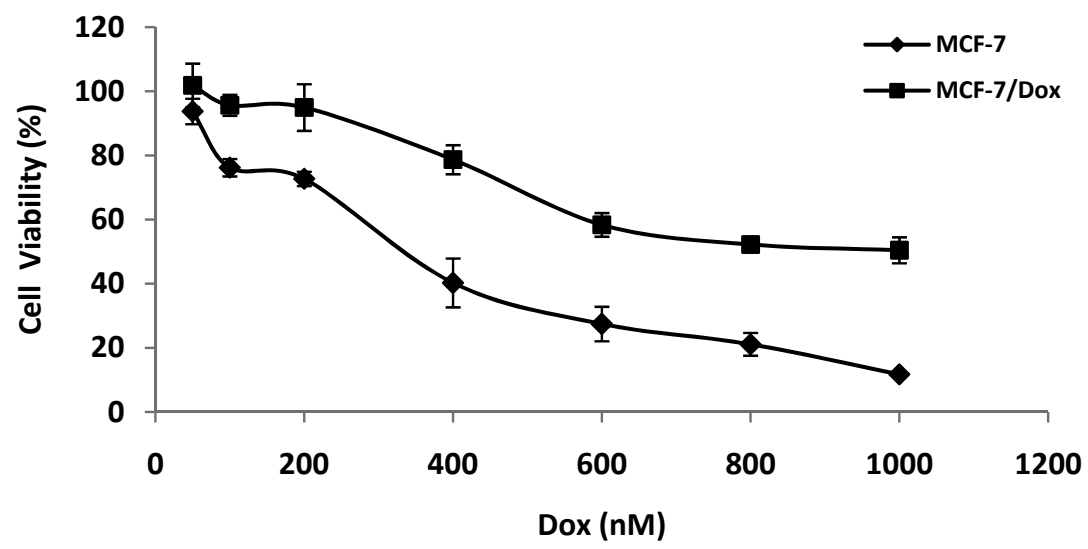

B

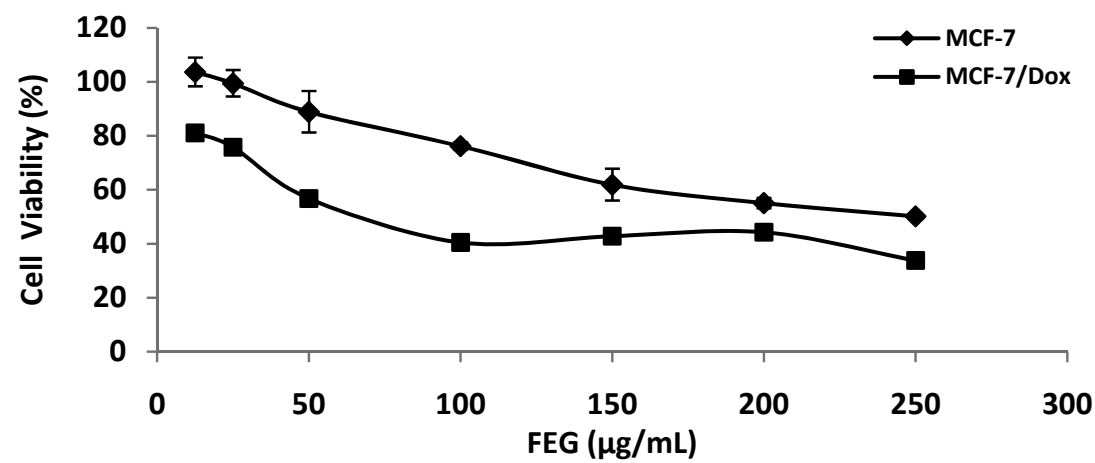

Figure 1. MCF-7/DOX cells are less sensitive to DOX (A) but more sensitive to FEG (B). Cells $\left(10^{4}\right.$ cells/well $)$ were cultured at $96-$ well plate, then treated with indicated concentration of DOX or FEG for $24 \mathrm{~h}$ incubation. Cells Viability was determined with MTT assay. This result represents from 3 independent experiments. The data was statistically analized by two tailedT-test analysis with $\mathrm{p}<0,05$.

\section{DOX induced the elevation of P-gp level}

DOX-induced MCF-7 cells showed the elevation of P-gp expression level in time dependent manner (Figure 2A). expression level of this protein was correlated with less sensitivity of MCF-7/DOX cells to DOX. FEG treatment decreased P-gp level in dose dependent pattern (Figure 2B). To make confirmation of this phenomenon, both immunobloting and immunofluorescence were conducted. FEG decreased the green fluorescence intensity that refer $\mathrm{P}$-gp protein decreasing (Figure 3). DOX induces breast cancer cell resistance due to increasing of
P-gp expression level. The P-gp protein has $170 \mathrm{kDa}$ molecule size. This protein is hyperglycosilated as such appears as a diffuse band on Western blot results (Patel et al., 2002). We also found the additional band below P-gp protein size (Figure 2). The lower molecules weight bands was detected using the JSB-1 antibody for P-gp represent degraded product of P-gp protein. JSB-1 antibody recognizes a cytoplasmic epitope of P-gp and does not cross-react with other protein such as MDR3 or muscle myosin, as does the C219 antibody (Leonessa and Clarke, 2003). 


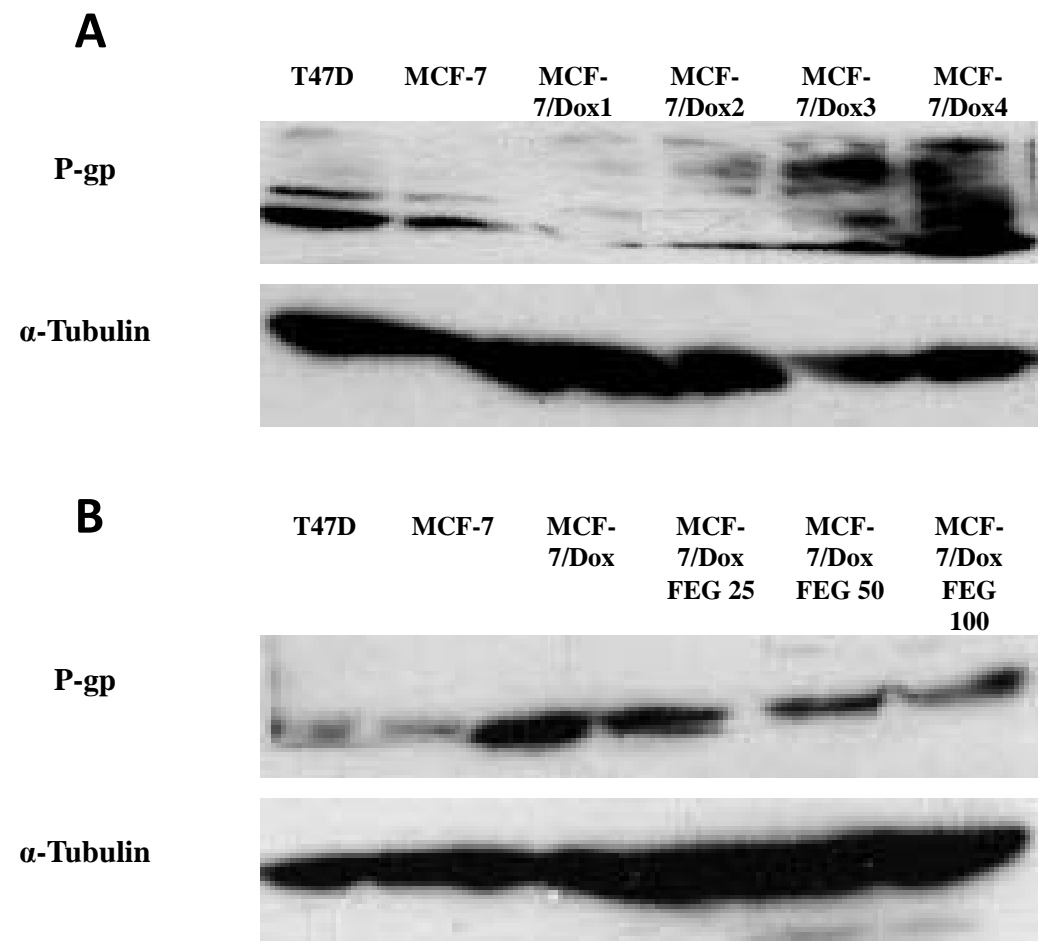

Figure 2. DOX induced P-gp expression on pada MCF-7 cells (A) and FEG prevents the elevation of this protein expression (B). Cells $\left(10^{6}\right.$ cells/well) were seeded at 6-well plate, then treated with DOX, FEG or its combination for $24 \mathrm{~h}$. Cell lysate then analyzed with Western blotting. Anti-a-tubulin was used for loading control. Dox1, Dox2, Dox3, and Dox4 refer to induction time for 2, 3, 4, and 5 weeks, respectively.

FEG reversed cell resistance and increased the sensitivity of MCF-7/DOX cells to DOX treatment

To investigate whether FEG could reverse the cell resistance development on MCF-7/DOX, MCF-7 cells were treated with DOX, FEG, or its combination and observed FEG reversal effect and its modulation on cell growth. Combination treatment of DOX+FEG suppressed cell growth o both of MCF-7 and MCF-7/DOX cells. The inhibition effect of combination treatment on MCF-7/ DOX cells more significance compared to MCF-7 cells (Figure 4).

\section{Discussion}

P-glycoprotein (P-gp), a protein encoded by MDR-1 gene, has important function as ATP-dependent pump of drug efflux. P-gp has specific substrate, such as vinca alkaloids, anthrasiclin, epipodhophylotoxins, and rhodamine. The exposure of These substrate to cancer cells could trigger transcriptional activity of MDR-1 (Germann, 1996; Lampidis et al., 1989; Nielsen et al., 1996).

Previous study have found the long time exposure of DOX induced cancer cells resistance through the increasing level of P-gp (Abolhoda et al., 1999). In this study MCF-7 cells were used as resistance model of breast cancer. This cells were developed by long term sub toxic concentration of DOX induction. MCF-7 cells are cell line that express MDR1 and Breast cancer resistance protein (BCRP) that will be triggered its expression after several chemotherapy agent induction (Faneyte et al., 2002). MDR-1 expression elevates at patient after long time chemotherapy agent administration and had strong correlation with cancer chemotherapy 
Nurulita et al.

I.J. Biotech.

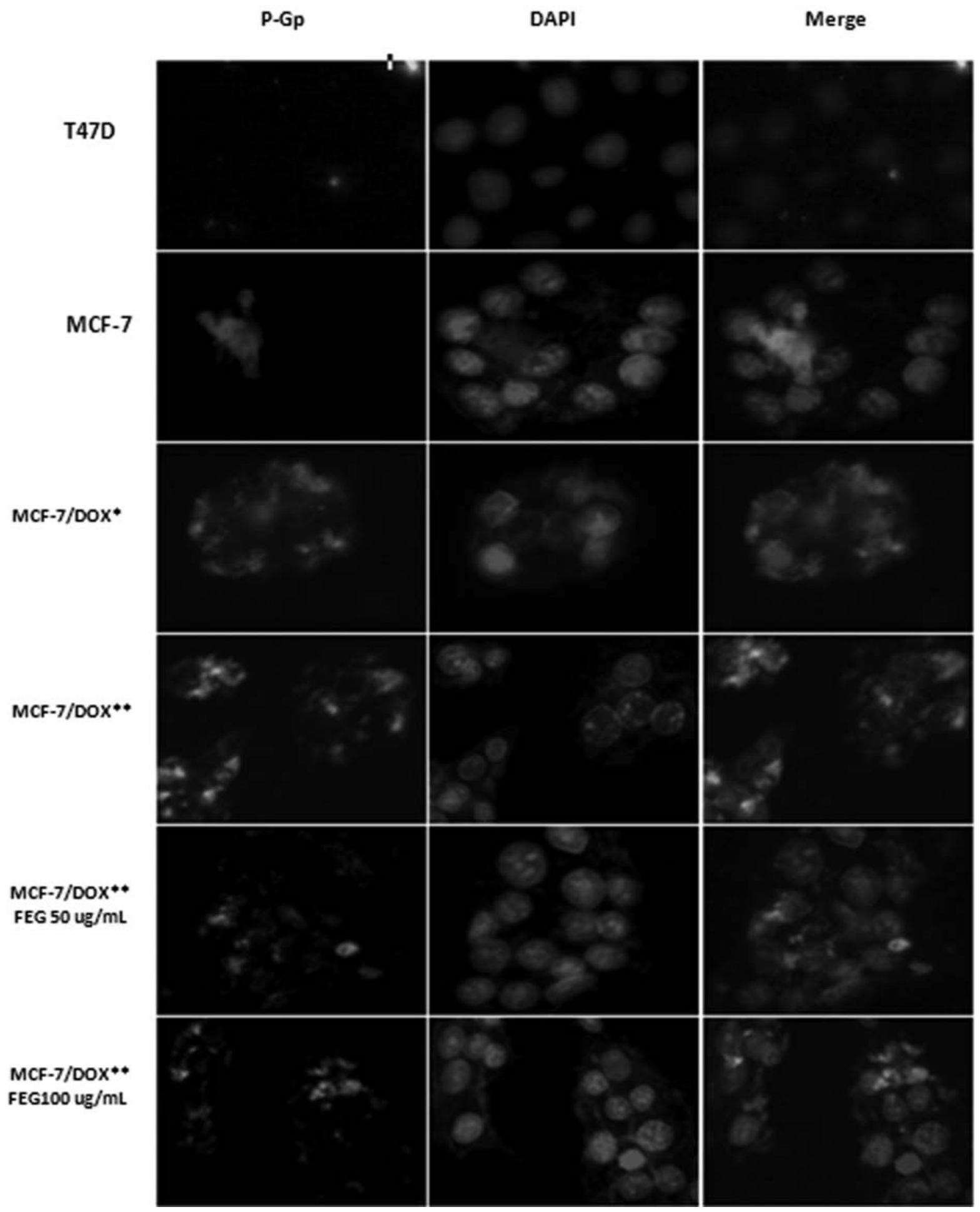

Figure 3. DOX induced P-gp expression on pada MCF-7 cells and FEG prevents the elevation of this protein expression in concentration dependent manner. Cells ( $5.10^{4}$ cells/well) were seeded on cover slip at 24 -well plate. After treated with or without DOX+FEG for $24 \mathrm{~h}$, then stained with anti-a-Tubulin (green fluorescence) and counterstained with DAPI (blue fluorescence). Cells were observed under fluorescence microscope with 400x magnification. 


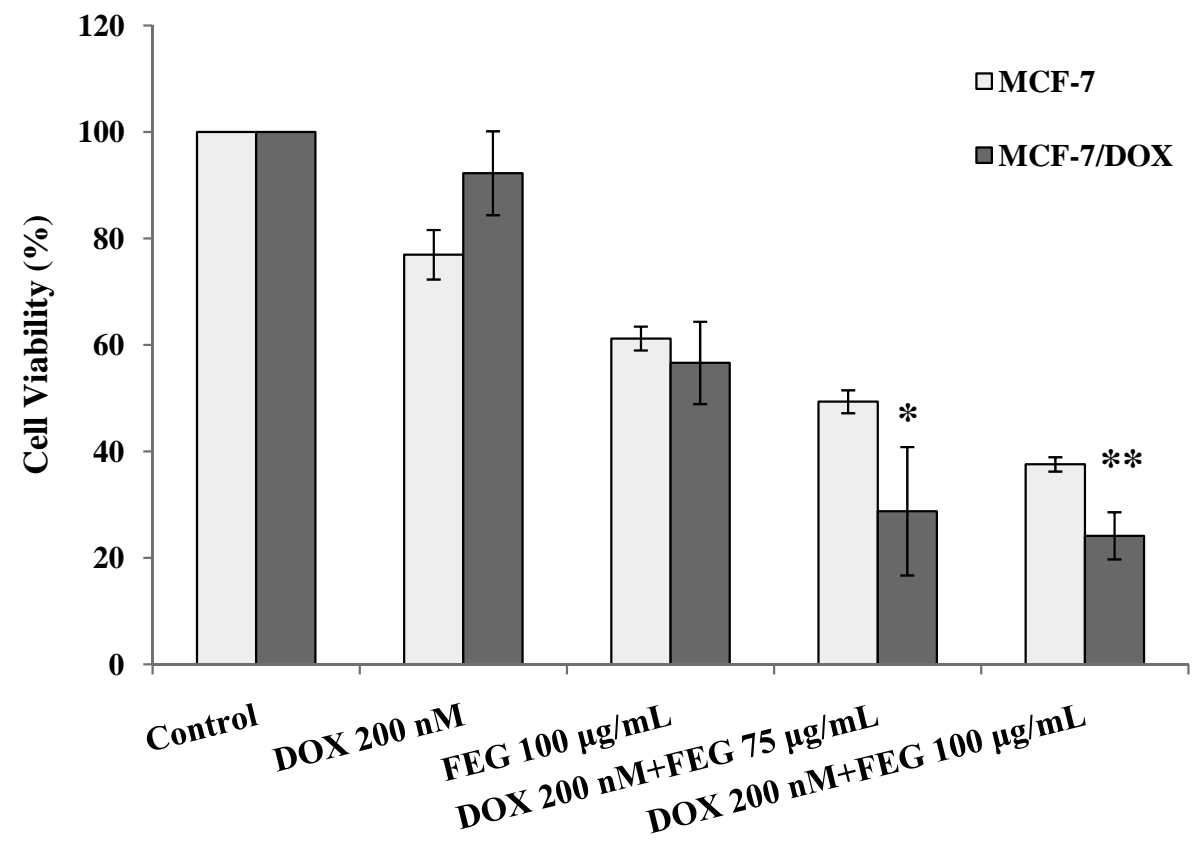

Figure 4. FEG increased the sensitivity of MCF-7/DOX cells to DOX. Cells ( $10^{4}$ cells/well) were cultured at 96-well plate, then treated with indicated concentration of DOX, FEG and its combination for $24 \mathrm{~h}$ incubation. Cells Viability was determined with MTT assay. This result represents from 2 independent experiments with similar results. The data was statistically analized by two tailed-T-test analysis. ${ }^{*} \mathrm{p}=0,1$ and ${ }^{* *} \mathrm{p}=0,028$.

failure (Leonessa and Clarke, 2003). This protein has identified as negative prognostic in cancer diseases development.

Sub toxic concentration of DOX for five weeks decreased MCF-7 cells sensitivity to this agent, shown by $\mathrm{IC}_{50}$ value become more than 2 fold higher compared with MCF-7 cells. DOX exposure to MCF-7 cells lead to increasing expression of $\mathrm{P}-\mathrm{gp}$ in time dependent manner. MCF-7 cells after five weeks DOX induction (MCF-7/DOX) shown the significance increasing of this protein level compared with MCF-7 cells. The P-gp level has strong correlation with the low sensitivity of MCF-7/DOX to DOX exposure.

The attempts to overcome drug resistance mediated by MDR-1 activation and elevation of P-gp level were developed the P-gp inhibitors. The agent that could suppress P-gp expression will increase uptake of chemotherapy agent and may influence its clinical efficacy. Flavonoids could modulate the expression and activation of P-gp. There are several mechanisms mediate their effect: changing membrane cells permeability, suppressing P-gp expression, inhibition ATPase activity, and occupation substrate binding site at P-gp, then changes its conformation (Arora et al., 2000; Boumendjel et al., 2002; Drori et al., 1995).

Natural compounds such as flavonoids and polyphenol have significant biological properties related to multidrug resistance development on cancer cells. Biochanin A and sylimarin inhibit drug efflux from the cells by P-gp pump, and produce synergistic effect when combined with DOX at MCF-7 and MDA435/LCC6. Both compound decreased $\mathrm{IC}_{50}$ value of daunomycin significantly at MCF-7/ Adr cells (Zhang and Morris, 2003; Chung et al., 2005). (-)-Epigallocatechin (EGC), (-)-epicatechin gallate (ECG), dan (-)-epigallocatechin gallate (EGCG) increase daunomycin accumulation at P-gp overexpressing cells, KB-C2 (Kitagawa et al., 
2004). Flavonoid and polyphenol have a promising properties to be developed as P-gp inhibitor to prevent cell resistance.

FEG treatment enhances DOX cytotoxicity significantly at MCF-7/DOX cells, higher than the effect on MCF-7 cells. The inhibition of cells growth exhibited synergistic effect of combination treatment DOX+FEG in dose dependent manner. FEG treatment decreases P-gp expression level at MCF-7/DOX cells linear to the given concentration. The ethyl acetate fraction of G. procumbens (FEG) was suggested have flavon and or flavonol with hydroxyl group modified to be metoksi at 3 and $4^{\prime}$, and asetoksi at 7 posisition (Sugiyanto et al., 2003). The ethyl acetate fraction of $G$. procumbens (FEG) may contain quercetin and kaempferol (Nurulita et al., 2012). FEG may modulate $M D R-1$ expression through the same mechanism with quercetin and kaempferol.

Quercetin inhibits the members of MDR1 family, such as: P-gp, MRP, and BCRP, competitively (Cooray et al., 2004; Scambia et al., 1994; van Zanden et al., 2005). Kaempferol and quercetin decrease P-gp expression and its activity at MDR KB-V1 cells (Limtrakul et al., 2005). Quercetin and kaempferol prevent cell resistance development through down regulate multidrug resistance gene on human erythroleukemic K562/ A cells. It reverses cells sensitivity to adriamycin (Yanqiu et al., 2011). Quercetin suppresses MDR1 expression and P-gp activity at human pancreatic carcinoma. The net influx of daunorubicin increases when given together with quercetin (Borska et al., 2010). One study on structure activity relationship concludes flavonoid with -OH group at 5 dan 7 , with maximal have three total hydroxyl groups, and have strong inhibition on P-gp activity. Double bond at $\mathrm{C} 2$ and 3 as shown at flavon generates its planarity, lead to intercalate with hydrophobic amino acids residue of P-gp (Sheu et al., 2010). Quercetin and kaempferol modulate both of MDR-1 gene and P-gp protein level and also its activity that reverse multidrug resistance on many type of cancer cell lines.
This study found that FEG decrease P-gp expression level at MCF-7/DOX cells. This results were suggested to the decreasing P-gp expression that may affect on the increasing of DOX accumulation at cancer cells. In the next study, monitoring the net uptake of DOX during co-treatment of FEG should be considered. This effect may precede through several possibility, such as suppression on transcriptional activity of $M D R-1$ gene, translation, or post translation.

As the conclusion, FEG prevents MCF-7 cells from developing resistance through down-regulating P-gp expression. FEG in combination with DOX potentiates the DOX effect on breast cancer cell growth inhibition. Thus, FEG could be developed as co-chemotherapy agent for reversing multidrug resistance.

\section{Acknowledgement}

This work was supported by Sandwichlike program 2010/2011, managing by Directorate General of Higher Education Republic of Indonesia, 2010

\section{References}

Abolhoda, A., Wilson, A.E., Ross, H. Danenberg, P.V.Burt, M., and Scotto, K.W.1999, Rapid activation of MDR1 gene expression in human metastatic sarcoma after in vivo exposure to doxorubicin, Clin. Cancer Res., 5, 3352-3356

Arora, A. Byrem, T.M., Nair, M.G., and Strasburg, G.M. 2000, Modulation of liposomal membrane fluidity by flavonoids and isoflavonoids, Arch Biochem. Biophys., 373, 102-109.

Borska, S., Sopel, M., Chmielewska, M., Zabel, M., and Dziegiel, P. 2010, Quercetin as a potential modulator of P-glycoprotein expression and function in cells of human pancreatic carcinoma line resistant to daunorubicin, Molecules, 15, 857-870.

Boumendjel, A., Di Pietro, A., Dumontet, C., and Barron, D. 2002, Recent advances in the discovery of flavonoids and 
analogues with high affinity binding to P-glycoprotein responsible for cancer cell multidrug resistance, Med. Res. Rev., 22, 512-529.

Chung, S.Y., Sung, M.K., Kim, N.H., Jang, J.O., Go, E.J., and Lee, H.J. 2005, Inhibition of P-glycoprotein by natural product in human breast cancer cells, Arch. Pharm. Res., 28(7), 823-828

Cooray, H.C., Janvilisri, T., van Veen, H.W., Hladky, S.B., and Barrand, M.A. 2004, Interaction of the breast cancer resistance protein with plant polyphenols, Biochem. Biophys. Res. Comm., 317, 269-275

Davis, J.M., Navolanic, P.M., WeinsteinOppenheimer, C.R., Steelman, L.S., Wei H., Konopleva, M., Blagosklonny, M.V., and McCubrey, J.A. 2003, Raf-1 and Bcl-2 induce distinct and common pathways that contribute to breast cancer drug resistance, Clin. Cancer Res., 9, 1161-1170.

Drori, S., Eytan, G.D., and Assaraf, Y.G. 1995, Potentiation of anticancer-drug Cytotoxicity by multidrug-resistance chemosensitizers involves alterations in membrane fluidity leading to increased membrane permeability, Eur. J. Biochem., 228, 1020-1029.

Faneyte, I.F. Kristel, P.M.P. Maliepaard, M. Scheffer, G.L.Scheper,R.J. Schellens, J.H.M. and van de Vijver, 2002, Expression of the breast cancer resistance protein in breast cancer, $\mathrm{Clin}$. Cancer Res., 8,1068-1074.

Germann, U.A. 1996, P-glycoprotein - mediator of multidrug resistance in tumor cells, Eur. J. Cancer. 32A, 927-944

Iskander, M.N., Song, Y., Coupar, I.M., and Jiratchariyakul,W. 2002, Antiinflamatory screening of medicinal plant G. Procumbens, Plant Foods Hum. Nutr., 57, 233-244.

Kitagawa, S., Nabekura, T., and Kamiyama, S. 2004, Inhibition of P-glycoprotein function by tea catechins in KB-C2 cells. J. Pharm. Pharmacol., 56, 1001-1005.
Leonessa, F. and Clarke, R. 2003, ATP binding cassette transporters and drug resistance in breast cancer, Endocr. Relat. Cancer, 10, 43-73.

Lampidis, T.J., Castello, C.,del Giglio, A., Pressman, B.C.,Viallet, P., Trevorrow, K.W. ,Valet, G.K., Tapiero, H., and Savaraj, N. 1989, Relevance of the chemical charge of rhodamine dyes to multiple drug resistance, Biochem. Pharmacol., 38, 4267-4271.

Limtrakul, P., Khantamat, O., and Pintha, K. 2007, Inhibition of P-glycoprotein function and expression by kaempferol and quercetin. J. Chemother., 17, 86-95.

Nielsen, D., Maare, C. and Skovsgaard,T.1996, Cellular resistance to anthracyclins, Gen. Pharmacol., 27, 251-255.

Notarbartolo, M., Poma, P., Perri, D., Dusonchet, L., Cervello, M., and Alessandro, N. 2005, Antitumor effects of curcumin, alone or in combination with cisplatin or doxorubicin, on human hepatic cancer cells. Analysis of their possible relationship to changes in NF$\mathrm{KB}$ activation levels and in IAP gene expression, Cancer Lett., 224, 53-65.

Nurulita, N.A., Meiyanto, E., Sugiyanto, Matsuda, E., and Kawaichi, M., 2012, Gynura procumbens modulates the microtubules integrity and enhances distinct mechanism on doxorubicin and 5-flurouracil-induced breast cancer cell death, Orient. Pharm. Exp. Med., DOI 10.1007/s13596-012-0063-5.

Nurulita, N.A., Meiyanto, E., and Sugiyanto, 2012, Selectivity of ethyl acetate fraction of Gynura procumbens on colon cancer and breast cancer, Indo. J. Cancer Chemoprev., 3(4)

Pattel, V.A., Dunn, M.J., and Sorokin, A. 2002. Regulation of MDR-1 (P-glycoprotein) by cyclogenase 2 . J. Biol. Chem., 277(41), 38915-38920.

Rosidah, Yam, M.F., Sadikun, A. and Asmawi, M.Z. 2008, Antioxidant potential of Gynura procumbens, Pharmaceutic. Biol., 46, 616-625. 
Scambia, G., Ranelletti, F.O., Panici, P.B., De Vincenzo, R., Bonanno, G., Ferrandina,G., Piantelli, M., Bussa, S., Rumi, C., and Cianfriglia, M. 1994, Quercetin potentiates the effect of adriamycin in a multidrugresistant MCF-7 human breastcancer cell line: P-glycoprotein as a possible target, Cancer Chemother. Pharmacol., 34, 459-464.

Sheu, M.T., Liou, Y.B., Kao, Y.H., Lin, Y.K., and Ho,H.O. 2010, A quantitative structure -activity relationship for the modulation effects of flavonoids on P-glycoprotein-mediated transport, Chem. Pharm. Bull., 58(9), 1187-1194.

Surowiak, P., Materna, V., Matkowski, R., Szczuraszek, K., Kornafel, J., Wojnar, A., Pudelko, M., Dietel, M., Denkert, C., Zabel, M., and Lage, H. 2005. Relationship between the expression of cyclooxigenase 2 and MDR1/Pglycoprotein in invasive breast cancers and their prognostic significance, Breast Cancer Res., 7, R862-R870.

Sugiyanto, B., Sudarto, Meiyanto, E., Nugroho, A.E., and Jenie, U.A. 2003, The anticarcinogenic activity of plants compounds, Indo. J. Pharm., 14(4), 216225.

Van Zanden, J. J., Wortelboer, H. M., Bijlsma, S., Punt, A., Usta, M., Bladeren, P.J., Rietjens, I.M., and Cnubben, N.H. 2005, Quantitative structure activity relationship studies on the flavonoid mediated inhibition of multidrug resistance proteins 1 and 2. Biochem. Pharmacol., 69, 699-708, 2005.

Yanqiu, H., Linjuan, C., Jin, W., Hongjun, H., Yongjin, S., Guobin, X., and Hanyun, R. 2011. The effect of quercetin and kaempferol on multidrug resistance and the expression of related genes in human erythroleukimia K562/A cells, African J. Biotech, 10(62), 13399-13406.

Zhang, S. and Morris, M.E. 2003, Effects of the flavonoids biochanin A, morin, phloretin, and silymarin on P-glycoprotein-mediated transport, J.Pharmacol. Exp. Ther., 304, 1258-1267. 